\title{
Arabic Handwriting Between Graphical Structural System and Aesthetic Reality
}

\author{
Labidi Bouabdallah \\ Department of Arabic Language and Literature, The College of Arts \& Letters, University of Blida 2 Lounici Ali, Blida, Algeria
}

Email address:

labidibouabdallah@yahoo.com

\section{To cite this article:}

Labidi Bouabdallah. Arabic Handwriting Between Graphical Structural System and Aesthetic Reality. Arabic Language, Literature \& Culture. Vol. 5, No. 3, 2020, pp. 35-43. doi: 10.11648/j.allc.20200503.12

Received: July 29, 2020; Accepted: August 12, 2020; Published: August 31, 2020

\begin{abstract}
Abstrat: The study aims at addressing -in esthetic approach- the Arabic calligraphy in its aesthetic and linguistic dimensions. The first dimension is highlighted in its distinctive aesthetic and cultural features within a set of propositions that achieve the concepts of pleasure and harmony. The second dimension appears in the nature of the patterns that control its graphical structure, to achieve linguistic/ communical and aesthetic/artistic functions. The nature of the artistic and historical approach to the phenomenon of Arabic writing, and the considerations that it produces, which feed into the traditional archaeological and aesthetic aspect, characterize this phenomenon with typical, normative and historical features, all of which are considerations upon which modern scientific studies in the humanities and social sciences have arisen, through studies that dealt with language - with its various elements - as a subject Can be described, interpreted, and analyzed objectively, which usually translates into the absolute Through Saussure's famous phrase "in and for itself" Whatever the trend that addressed the phenomenon: structural, functional, systemic, behavioral, or cognitive. It is certain that it was able to highlight the topic clearly... and define the appropriate approach - or approaches - to reveal what the conceptual record is and to reach the desired goals. With the diversity of schools and the accumulation of knowledge - the phenomenon of Handwriting as one of the aspects of linguistic evidence has become a subject that we can approach with a systematic linguistic vision without removing from it the features of the aesthetic that performs its distinctive, cultural and cognitive functions. The research concluded that the Arabic calligraphy with its epistemological potential resulted from the deposits of aesthetic practices, which supplied it with aesthetic shipments that could not be decomposed. The research combines between linguistic and aesthetic concepts, thus allowing the connection of linguistic field to artistic and historical issues, which is what we refer to as cultural linguistics.
\end{abstract}

Keywords: Arabic Handwriting, Graphems, Graphical Structure, Aesthetics

\section{Introduction}

"Beauty" is synonymous with art; two similarly puzzling fantasy worlds. They are hard to define, cannot be measured against fixed standards, progress rapidly and are replete with novelty.

Harmony of natural elements, congruence of components and compatibility of diverse parts are vital for the subsistence of the whole universe. That is why appreciating the aesthetic value of its components is a fundamental theme, which is based on coherent parts and homogeneous features, and helps to gain a comprehensive understanding of the world. It examines the structure, mechanism and aesthetic secrets of these components, and covers all fields of knowledge, including history, philosophy, sociology, psychology, culture, linguistics, ethics and the advancement of humankind.

There is no doubt that Arab and Islamic civilization has attached great importance to aesthetic expressions in all fields of life. Thus, it has mastered the art of using aesthetic language to describe man's words, actions, abode, travels, peace, war, motion and stillness using sounds, colors and strokes, guided by the texts of the Holy Quran and the noble Sunnah.

As Arabs tended to use an aesthetic and gentle language that would comprise elevating ideas, amusing vocabulary, highly rhythmical and rhetorical verse, and evocative rhymed prose, this aesthetic tendency manifested itself in Arabic 
calligraphy, as "pictorial discourse" that performs a variety of functions, not least of which is the communicative, aesthetic and effective function. It is also regarded, from a linguistic perspective, as an alternative, rather than secondary, manifestation of spoken language. As a result, the great aesthetic value of this calligraphy has had a very wide appeal, after the message of Islam, the religion of truth, spread all over the world.

With this in mind, this study adopts a descriptive and analytical method to depict the most important calligraphical elements and aesthetic coordinate features of Arabic calligraphy, guided by a linguistic and aesthetic approach.

This involves providing an overview of the Islamic approach to calligraphy, with all its iconic elements and graphical systems. After that, the study tackles the development of the artistic types of Arabic calligraphy throughout history. Muslim calligraphers have excelled at this art, with the purpose of elevating art enthusiasts' taste, fancy and knowledge, and giving the world a true and graceful picture of Muslim-Arab civilization. This art is an incarnation of vividness and efficiency, and has spiritual, aesthetic and linguistic aspects; it is more than a mechanical process of transcription.

It is worth noting that the aesthetic dimension of Arabic calligraphy, as an artistic and aesthetic practice, allows calligraphers to demonstrate its artistic features and fulfill its communicative function at the same time.

\section{The Islamic Approach to Calligraphy, with All Its Iconic Elements and Graphical Systems}

First, it should be noted that it is part of human nature to be attracted to beauty in all aspects of life. Moreover, all heavenly religions, especially Islam, seek to enhance this inclination.

"Aestheticism" is closely linked to two concepts, namely pleasure (or enjoyment) and harmony. This relation is manifested in motion, sound, color, shape, one's outfit, behavior, ways of thinking, and psychological and social interaction:

The term "pleasure" is used 70 times in the Holy Quran, in various derivatives and within different contexts. Pleasure is the ultimate end of art and aesthetics, and the term stands for all that makes one feel total relief, infinite psychological peace and utter amazement. Denis Huisman suggests that "the only distinctive feature of art is ecstasy", and that "art ends when it loses its delight"(1).

However, Islam aims to grant all humans absolute peace of mind, with regard to all that relates to worldly life and the hereafter. In the Holy Quran, this feeling is termed

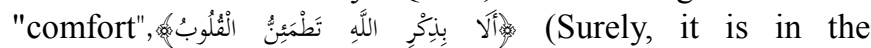

1 Denis Huisman, Aesthetics, translation: Zafer Al-Hassan, The National Company for Publishing and Distribution (snad), Reghaia, Algeria, 1975, $2^{\text {nd }}$ ed. P.122. remembrance of God that hearts find comfort) $)^{(2)}$, "relaxation", (And there is beauty in them for you, when you bring them home) ${ }^{(3)}$ (i.e. when you relax), and "solemnity", in their prayers) $)^{(4)}$ (i.e. who perform the prayer solemnly).

As for the harmony between elements and components of various types, physical and abstract ones, it is evident in a variety of natural phenomena, including:

\subsection{Harmony in Astronomical Phenomena}

The story of prophet Abraham provides conclusive evidence for the impact this harmony has on humans; he adopted Islam after long meditation on these astronomical phenomena. That is why the Almighty swears by night and

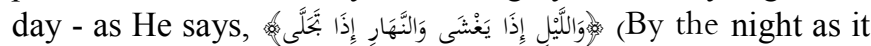
covers. And the day as it reveals) $)^{(5)^{\prime}}$ - as two signs of His

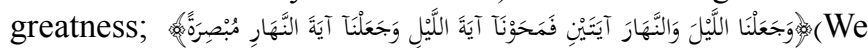
have made the night and the day two wonders. We erased the wonder of the night and made the wonder of the day revealing). ${ }^{(6)}$

Since aesthetic values have great individual and collective appeal that is reflected in strong feelings or manifested in action, the Holy Quran and Sunnah drive the human soul to use sound judgment and good taste to examine, meditate upon and ponder over the magnificence of creation, with the purpose of having those who deny the existence of the Creator believe in Him and helping the believers have stronger faith. This is evident in the following verse:

(Say, “Onserve at what is in the heavens and the earth".). ${ }^{(7)}$

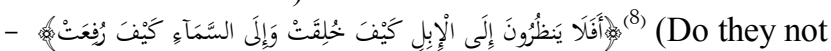
look at the Camels - How they are created? And at the sky how it is raised?)

(Or do they have eyes by wich they see?)

The term "beauty" is used only once in the Holy Quran, in a verse that describes how the Almighty has committed creatures to our service; (And there is beauty in them for you, when you bring them home, and when you drive them to pasture.) (10) Aestheticians suggest that "beauty" could be defined as "whatever gives us overwhelming and true joy"(11), or "whatever we may feel - without a shadow of a doubt - an irresistible urge to be delighted". ${ }^{(12)}$

On the basis of this principle, many Hadiths make it clear that giving a Muslim joy is one of the best deeds one may do;

\footnotetext{
2 Al- Ra'd, 29.

3 Al- Nahl, 06.

4 Al- Mu'minun, 02.

5 Al- Layl, 1-2.

6 Al- 'Isra', 12.

7 Yunus, 101.

8 Al- Ghashiya, 17-18.

9 Al- A'raf, 195.

10 Al- Nahl, 06

11 Denis Huisman. 1975, p.59.

12 Denis Huisman. 1975, p.60.
} 
for example, it is reported that Omar bin Al-Khattab said, "the Prophet, peace be upon him, was asked about the best deed one may do. He said, 'to bring pleasure to a Muslim...".(13)

\subsection{Harmony in Linguistic Phenomena}

This harmony can be felt in both poetry and prose, and its most notable feature is rhythm, which is the distinguishing characteristic of all meters of Arabic poetry, the record of Arabs. It is also evident in the artistic aspect of discourse, which is usually termed "sound devices". These include antithesis, paronomasia and paradox, and they amount to 150 devices. ${ }^{14}$ This is not to mention the morphological, semantic, rhetorical and expository aspects of Arabic poetry, commonly termed "figures of speech".

These artistic and stylistic techniques are used as a means of articulating Quranic miracles that have dazzled, delighted and convinced some people, including Arabs and non-Arabs, to convert to Islam, while others have denied them, despite their being deeply moved by them; ;

(And they rejected them, although their souls were certain of them). ${ }^{(15)}$ Al-Walid bin Al-Mughira, a polytheist who was well-versed in all poetic genres, recognized that the Holy Quran was a miracle that resembled neither verse nor prose.

Men of letters and critics of all times have committed themselves to exploring aesthetic aspects in literature; some of them suggest that these aspects reside in the form, while others believe that they are attributed to the sense, as detailed in works on literary criticism and rhetoric. ${ }^{(16)}$

However, linguistic phenomena that reflect aesthetic values promoted by the Holy Quran and Sunnah are closely related to two other aspects of utmost importance, translation and writing (or Arabic Script)

\subsection{Translation}

Translation is indispensable for human communication, community and social cohesion, and the transmission of thought, literature and knowledge from one culture to another, within a framework of sublime and constructive values governed by specific linguistic controls and more general epistemological ones.

From an Islamic perspective, linguistic and cultural diversity is viewed as an aspect of human communication, and an important feature of the beauty of creation and the Creator's infinite power; كَاِ

13 Al-TTabarani, Sulayman bin Ahmad, The Middle dictionary, Invest: Tariq bin Awad bin Muhammad, and Abdul Mohsen bin Ibrahim Al-Husayni, Dar AlHaramayn, Cairo, 1995. \& Al-Haythami, Ali bin Abi Bakr, Majma'Al-Zawaed, Al-Rayyan Heritage House, Cairo, \& Dar Al-Kitab Al-Arabi, Beirut, 1987.

14 Abd Al-Ghani Al- Nabulsi, Nafahat Al- Azhar. World of Books, Beirut, \& AlMutanabi Library, Cairo.

15 Al- Naml, 14

16 Abd Al-Qahir Al-Jurjani, Dalail Al- Ijez, invest: Mahmoud Muhammad Shakir Al-Khanji Library \& Al-Madani Press, Cairo. \& Adel Hadi Hammadi Al-Ubaidi, (The Issue of Pronunciation and Meaning), within journal of "Al-Ustaz", 2013, Issue. 201.

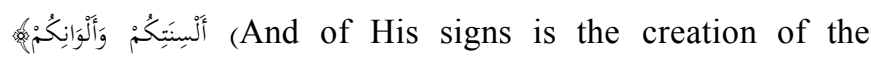
heavens and the earth, and the diversity of your tongues and colors). ${ }^{(17)}$ Al-Ahwazi (d.279 AH) said, "Tongues' means languages". ${ }^{(18)}$

Zayd bin Thabit said that the Prophet ordered him to learn "the writing of the Jews". Zayd said, "only a fortnight passed before I mastered it. I would write for him when he wrote (to them), and read to him when something was written to him". (19)

Likewise, Muslims are allowed to learn languages, other than Arabic, such as the languages that were known to Arabs when the Quran was revealed, including Syriac, Hebrew, Hindi, Turkish and Persian. ${ }^{(20)}$

Prophet Moses also pleaded with the Almighty to "untie the knot from [his] tongue", so that he would deliver His message most clearly, for he spoke with a lisp after he had stayed in Median for a long period of time. The Almighty

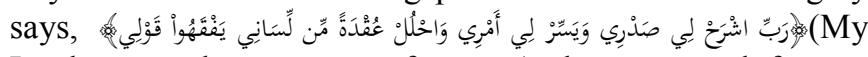
Lord, put my heart at peace for me. And ease my task for me. And untie the knot from my tongue. So they can understand my speech) ${ }^{(21)}$.

In modern times, there have been calls for a peaceful coexistence of all human races, which have diverse languages and cultures. This is usually termed "linguistic and cultural tolerance". It involves the acceptance of linguistic and cultural diversity, with the purpose of developing human civilization and strengthening human relationships. ${ }^{(22)}$ As a matter of fact, this approach to human relations is based on a proper understanding of different cultures, and it should be based on a comprehensive world view.

Linguistic tolerance would enhance cultural cooperation between diverse human races and urge all members of the international community to seek cultural and intellectual communication, as a key feature of human civilization. Translating books into world languages is of vital importance to achieving this objective. ${ }^{(23)}$

This brings up a sensitive issue associated with linguistic, religious and ethnic diversity; the claim that some languages are superior to others. Ibn Hazm tackled this issue 10 centuries ago. He says, "some people mistakenly believe that their language is the best. This claim is groundless because the common criteria for favoring some people to others are good deeds and distinction. One's language can never be deemed an advantage, and no Quranic verse states that a language is superior to another, but rather the Almighty says, (We never sent any

\section{Al- Rum, 22}

18 Al-Mubarkafuri, Abu Al-A'la, Tuhfat Al-Ahwadhi, Dar Al-Kutub Al-'ilmiyya, Beirut, 1990, $1^{\text {st }}$ ed.

19 Al-Mubarkafuri, Abu Al- A'la, 1990.

20 Al-Mubarkafuri, Abu Al- A'la, 1990.

21 Taha, 25-28.

22 Al-Makki Al- Nasiri, The Constitution of Tolerance in Islam, (without informations). P. 60.

23 Ammar Djidel, Dialogue of Civilizations and the Qualifications of Islam in Establishing Humanitarian Communication, Dar Al-Hamid for Publishing \& Distribution, Amman, Jordan, 2003, p.52. 


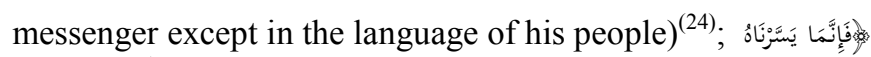

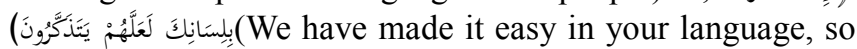
that they may remember) ${ }^{(25)}$."

The Almighty explains that the only reason why the Holy Quran is in Arabic is to make it easy for the Prophet's people to understand it. Galen expresses an invalid view as he suggests that "Greek is the best language, due to the fact that all other languages sound like barking or croaking". In response to this, Ali says, "this is utter nonsense! Whoever hears a language he does not speak will probably think of it as gibberish, and Greek is no exception". (26).

Then he adds, "divine revelations were sent down to prophets in all human languages; the Torah, the Gospel and the Psalms were originally in Hebrew, the language the Almighty used to address Moses. However, the texts that were revealed to Abraham were in Syriac. Accordingly, no language can be considered superior to another". (27)

Moreover, prominent linguists, especially de Saussure, study linguistic phenomena from a universal perspective, i.e. all human languages and individual performances of these languages are the subject of linguistics. ${ }^{(28)}$

With all these facts in mind, how can anyone be deceived into believing that some nations should be considered superior to others at all times? How can anyone fail to use their judgment to recognize the axioms of the linguistic phenomenon, that they are deceived into thinking that some, rather than all, languages are a good means of expression. ${ }^{(29)}$

\subsection{Handwriting (or Arabic Script)}

Before touching on the major role given to writing or calligraphy in Islamic civilization and the Islamic perspective on this art, we should define the term "calligraphy", so as to include the linguistic, semiotic, artistic and aesthetic dimensions of this art.

In linguistic terms, language is defined as a set of signs or marks, and "the linguistic sign" consists of the signifier and the signified. ${ }^{(30)}$ Linguistic items, as suggested by Abd alSalam Masaddi, would have had no semiological significance unless there had been a process of collective association between concepts and linguistic signs. Members of the same group can never express meaning without linguistic expression. ${ }^{(31)}$

This is also the case with written signs or symbols; each grapheme represents a phoneme, which becomes a signifier

24 Ibrahim, 4.

25 Al- Dukhan, 58.

26 Ibn Hazm Al-Zahiri, Ali bin Ahmed, Al-Ihkam Fi Usul Al-Ahkam, Imam Press in Egypt, $1 / 32$.

27 Ibn Hazm Al-Zahiri, 1/32

28 Ferdinand De Saussure, Cours de linguistique générale, édition critique, Preparation: Fullio de Mauro, ed Payot, 1980.

29 Abd Al-Salam Al-Masaddy, (Formulation of the term and its theoretical foundations), within the book: "The Foundation of the terminological Issue", prepared by: a group of university researchers, the National Institute for Translation, Investigation \& Studies, House of Wisdom, Cartage, Tunis, 1989, p.17.

30 Ferdinand De Saussure, 1980, p.47.

31 Abd Al-Salam Al-Masaddy, 1989, p.34. when joined by other phonemes. This applies to both handwritten and printed pieces of writing. ${ }^{(32)}$

Hence, graphemes and phonemes are two sides of a linguistic sign as shown in the figure 1:

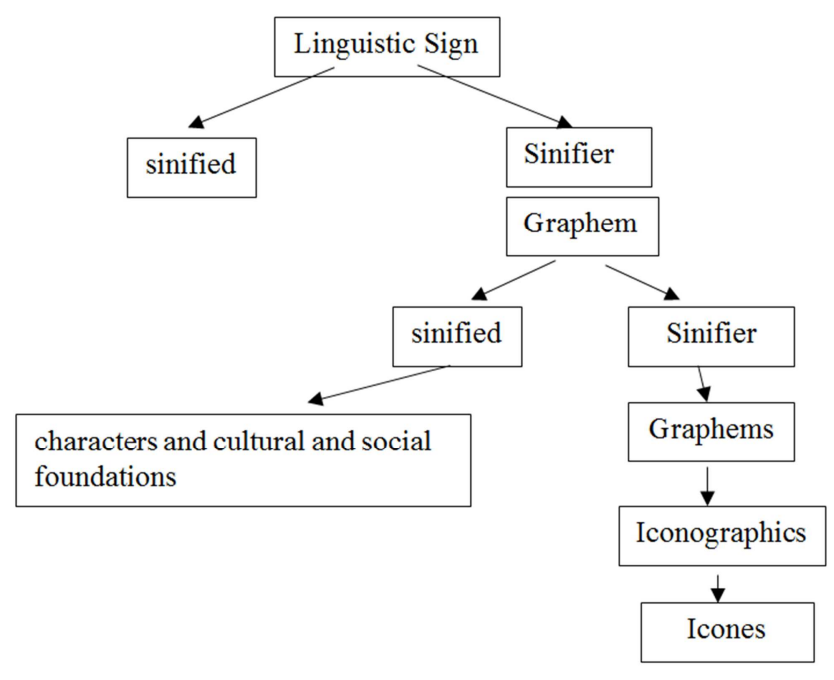

Figure 1. “Graphem”(33).

Thus, I can suggest that the written symbol is a sign that has three dimensions:

A formalistic (pictorial) dimension:

It gives written symbols their artistic value and characteristics, as a graphical structure composed of several graphemes or graphical units. Each unit comprises graphic icons within a calligraphic system, format or structure. Thus, calligraphy can be defined as "artistic strikes or figures that represent words, which, in turn, are a means of articulating one's inner thoughts" ${ }^{(34)}$

It should be noted that association is the principle that governs semiotic relations. This is because each figure "carries a sense, owing to the association between the signifier and the signified". (35)

A phonological dimension: It defines the phonological functions of written symbols.

A cognitive/aesthetic dimension: It is manifested in a person's ability to join graphemes together, based on their knowledge about semiotic relations, within systems of patterns and figures apprehended by the human mind.

This dimension of the writing process is related to the aesthetic function; like phonemes (sound units), graphemes (written units) are not abstract units. They form a structure that comprises graphic units associated with phonological properties.

Hence, the writing system is a set of graphic symbols that

32 Salim Al- 'Alawi, (Sultan of the Spoken and Written), within the journal of "Language \& Literature". University of Algiers. 1996. Issue. 09, p.25.

33 Labidi Bouabdallah, (The concept of calligraphy and its functions, a linguistic, semiotic approach), within the Journal of Arts \& Languages, 2007, Issue. 02, p.199.

34 Ibn Khaldun, Abd Al-Rahman, Al-Muqaddimah, School Library and Lebanese Book House for Printing \& Publishing, Beirut, 1979, 1/744.

35 Qasim Siza \& Abu Zayd Nasr Hamid, Introduction to Simiotics: Translated Articles \& Studies, (without information), 2/81. 
represent signifiers, i.e. graphemes that comprise graphic icons. These graphemes are commonly termed letters.

The writing system is a combination of letters, graphic units that have phonological properties and a cognitive/ aesthetic dimension, as illustrated in the figure 2 :

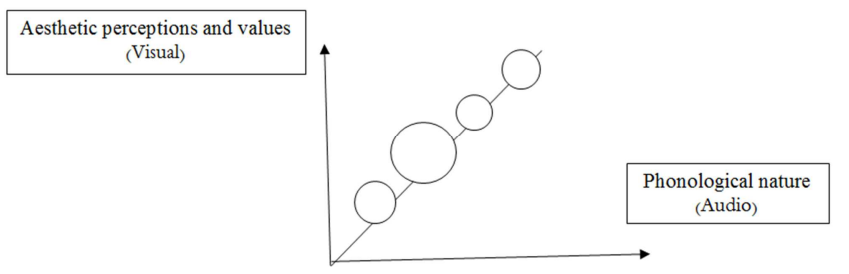

Figure 2. "The phonological and aesthetic dimensions of graphemes" 36

Accordingly, letters are endowed with phonological properties represented by graphic icons, and aesthetic value of various levels that range from artistic calligraphy to bad handwriting.

Writing combines phonological properties and aesthetic value with linguistic and other functions, which include the communicative, documentary and aesthetic functions.

An in-depth study of Islamic civilization would reveal that great importance is attached to writing. This is evident in the following:

\subsubsection{Quranic Emphasis on the Importance of Writing}

This is evident in the fact that the first Quranic verse revealed to the Prophet calls people to read, and reading is impossible without written material. Moreover, a chapter of the Holy Quran is entitled "al-Qalam" (Arabic for The Pen), and the Almighty swears by "the pen" in the opening verse of this chapter; as the Almighty swears by something, it is indicative of its enormous importance. As

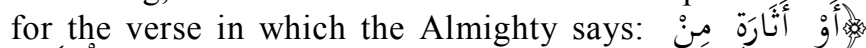
عِلْم (or some trace of knowledge) (37), Ibn Ábbas (d.68 $\mathrm{AH})$, Mujahid (d.104 AH) and Abu Bakr bin Ayyash (d.193 AH) suggest that the intended meaning is "a piece of writing". (38)

\subsubsection{Freedom in Return for Teaching Writing}

Muslim historians report that the Prophet used to set prisoners of war free in exchange for teaching the children of the Supporters (the people of Medina) writing. Ibn Abbas said, "Some of the captives of Badr could not pay the ransom, so the Prophet promised to release them in return for teaching the children of the Supporters writing" ${ }^{(39)}$. Accordingly, every captive was released after teaching 10 children reading and writing. This indicates that writing is as valuable as freedom, as both may rid one of something negative; the former is an end to slavery and captivity, while the latter is an end to illiteracy and ignorance.

36 Labidi Bouabdallah, 2007, p.201

37 Al- Ahqaf, 4.

38 Ibn Kathir, Isma‘il bin Omar, Tafsir bin Kathir, Dar Al-Fikr, Beirut, 1981.

39 Muslim bin Al-Hajjaj Al-Nisaburi, Sahih Muslim, 1912, p.58.

\subsubsection{Muslim Philosophers' Attitude Towards Arabic Calligraphy}

In my opinion, no type of calligraphy has embodied human thought throughout the ages as Arabic calligraphy has done, owing to its aesthetic vividness and philosophical dimensions

As writers and calligraphers need to learn the technical rules and aesthetic standards of calligraphy, philosophers and theologians have contributed to exploring this art, identifying its patterns, defining its graphical units, which have visual and abstract forms, promoting pictorial expression, as a basis of calligraphy, and explaining the meanings associated with each graphic unit.

Their motivation for studying this art might be the exploration of the symbolic properties of each graphic unit, as a figure that embodies various cognitive and aesthetic conceptions. The following is a summary of contributions made by some of these scholars.

\section{(i). Graphic Elements in the Epistles of the Brethren of Purity (Rasa'il Ikhwan Al-Safa):}

Muhammad Al-Mri summarizes the Brethern of Purity's approach to writing; they believe that letters embody the numerical and formalistic values of the larger world - the universe - and the smaller world - the human body ${ }^{(40)}$. Both have been made by the Creator. They suggest that "an example of a natural phenomenon, of the larger world, associated with the number 28 , the number of Arabic letters, is the lunar phases. There are 28 lunar phases; 14 phases over the Earth and 14 others beneath the Earth. They can be observed as they occur at the right and left sides of the Moon. Fourteen phases occur in northern constellations, while the others occur in southern ones. Similarly, the human body contains organs associated with this number". (41)

Pierre Lory suggests that these perspectives are part of the "geometry of the spirit (the study of the letters of the Arabic alphabet as symbolic qualities) that is based on logical associations between letters, numbers and the universe". (42)

In addition to Arabic calligraphy, numerical compatibility is associated with poetry, mathematics and music, as it "creates harmony between these systems." (43)

\section{(ii). Ibn Arabi's Perspective on the Letters of the Arabic Alphabet}

Muhyi Al-Din bin Arabi (d. $638 \mathrm{AH}$ ) treats letters as a nation similar to human nations; they can be addressed and have duties to fulfill. Some of them were chosen to be messengers, and they all have names. This is to be recognized only by those of enlightened minds. For him, the world of letters surpasses all other worlds in terms of eloquence, and this world comprises a variety of elements, as

\footnotetext{
40 Muhammad Al-Magri, The Form and The Discourse, An Introduction to Phenomenal Analysis, The Arab Cultural Center, Beirut, 1991, $1^{\text {st }}$ ed, p.116.

41 Al-Safa Brothers and Khillan Al-Wafa, Al-Safa Brother's letters, Dar Sader, Beirut, 3/143.

42 Pierre Laurie, The Science of Letters in Islam, see: Dalia Al-TToukhy, The Egyptian General Book Authority, Cairo, 2006, $1^{\text {st }}$ ed, p. 109.

43 Pierre Laurie, 2006, p.109.
} 
is the case with our world. ${ }^{(44)}$

Such attitudes can be ascribed to the belief that what graphic icons represent is greater than what is visible to the naked eye, and that universal phenomena are open to countless interpretations and associations. ${ }^{(4)}$

In short, Muslim philosophers view the system of writing and its graphic elements as a world that they need to meditate upon. It offers "food for thought" as it abounds in countless secrets and welcomes all interpretations.

\section{The Development of Arabic Calligraphy Styles Throughout the Ages}

The roots of Arabic calligraphy can be traced back to Sumerian pictography that developed into the Canaanite alphabet, which gave birth to Aramaic and, then, Nabataean, the mother language of Arabic in its present form. ${ }^{(46)}$ It is characterized by its simple graphic forms and, like most writing systems, its random associations. Accordingly, the development of Arabic calligraphy can be compared to the development of a human being, who is created from dust, then from a small drop, then from a clinging clot, and then from a lump of flesh. After being born, the human being experiences physical changes throughout his life and ends up as an old person. Indeed, humans are created in the best

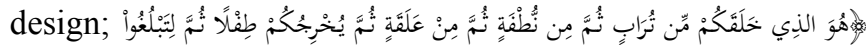

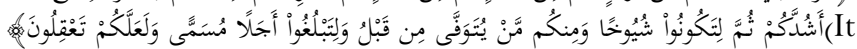
is He who created you from dust, then from a seed, then from an embryo, then He brings you out as an infant, then He lets you reach your maturity, then you become elderly -although some of you die sooner- so that you may reach a predetermined age, so that you may understand) $)^{(47) . ~}{ }^{(47)}$.

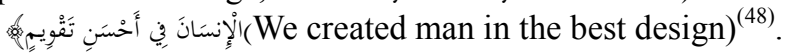

Arabic calligraphy went through two main phases; the first phase was marked by "difficult birth", as explained above, while the second was marked by continuous modification and improvement, as "harakat" (vowel marks in Arabic script), diacritics and ornamentation were introduced, and the rules of proportional spacing were set.

These formalistic, linguistic, artistic, and aesthetic transformations resulted in a variety of styles, mentioned in the literature on calligraphy, which embody the effectiveness of these modifications and an aesthetic vision that helped to reflect the political, social, philosophical, intellectual and epistemological nature of the times during which these styles emerged. Therefore, I believe that calligraphy is one of the

44 Ibn Arabi Muhammad bin Ali, The Meccan Conquests, invest: Osman Yahya, review: Ibrahim Madkour, the Egyptian General Book Authority, Cairo, p.260.

45 John Lake Shalimu, The Graphical Icon, translation: Amara Kahali, within journal of "Semiotics", published by the Laboratory of Semiotics and Speech Analysis, University of Oran, Algeria, 2005, Issue. 01, p.128.

46 Ahmad Al-Mufti, Arabic calligraphy rules, Dar bin Kathir, Dar Al-Qadiri \& Damascus \& Beirut, 1997, $1^{\text {st }}$ ed, p.09.

47 Ghafir, 67.

48 Al- Tin, 04. most important means to assess cultural, scientific, and intellectual development in particular, and the advancement of civilization in general. This is most evident in the fact that the styles of Arabic calligraphy saw aesthetic breakthroughs during the Abbasid and Andalusian eras. This included soft and hard styles that were made more pliable and ornamented with graphic and iconic items.

A synchronic examination of these styles, as listed in the literature, would show that Arabic calligraphy has seen ontological development since the early Islamic era.

Ejaze, Al-Basri, Al-Badi, Al-TTahrir, Atidhkari, ta'liq, (Persian), Tawqi'at, Thuluth (Thaqil, jali, Khafif, and compound), Thuluthayn, Jalil, Al-Jawanihi, Hejazi, AlHaram, Al-Kharfaj, Al-Ddaraj, Al- Ddibaj, Al-Diwani, Diwani Al-Jali, Al-Riqqa', Raqq‘a, Al-Rayhani, Al-Riyasi, Al-Zunbur, Al-Mofatah, Al-Sijillat, Al-Sunbuli, Asiyaqt, AlSli'ar, Al-shikiste, Tughra', The Great Tomar, Al-'U'hud, Dusts of Ornament, Stories, Al-Gyramuz (or byramoz), AlKayrawani, Kufi (in all its forms: Andalusian, Simple, flowered, plaited, leafy, wooded, geometric, square (or quadratic), Pearly, Mu'akhadhat, Mu'amarat, Mu'allaf, Mabsut, Majmu', Muhdath, Mukhaffaf, Mukhalla', Mudmaj, Al-Madani, Al- Mursal, Al-Musalsal, Al-Mushafi, AlMu'allaq, Al-Maghribi: Tunisian, Al-Thulth, Al-Jazayri, AlZimami (Al-Musnad), Al-Sudani, Al-Fasi, Al-Kufi, AlMabsut, Al- Mujawhar, Al-Mashriqi), Al- Mufattah, AlMuqtarin, Al- Muqawwar, Al- Makki, Al- Manthur, AlMansub, Al- Mamzuj, Al- Nas-ta'liq, Al- Naskh, Atabiki Naskh, Ayoubid Naskh, Mamluk Naskh, Al- Nisf, Nisaburi, Nisaburi, Hamayouni ${ }^{(49)}$

These styles can be studied from two perspectives; a chronological perspective and a spatial perspective.

- From a chronological perspective, Arabic calligraphy has developed over a long period of time, starting with the early Islamic era, the Abbasid era, the Fatimid era, the Andalusian era, the Seljuq era, the Mamluk era and the Turkish era...etc.

- From a spatial perspective, Arabic calligraphy has been given more attention in specific cities, including Kufa, Damascus, Baghdad, Cordoba, Kairouan, Persia (Nessapur for example), Istanbul, Cairo and Fez... etc.

This temporospatial approach helps us to understand the changes that the graphic styles of Arabic calligraphy have gone through, and recognize how much importance has been attached to this art.

It swept across the vast Muslim state, and those styles had a halo of sanctity and spirituality that was associated with the sanctity of the Quranic script. The multiplicity of these styles proves to those interested in studying Arabic calligraphy that its prominence has never abated since it emerged. This vividness has encouraged non-Arabs to use these styles to

49 Al-Qalqashandi, Abu Al-Abbas, Subh Al-A'sha, the Egyptian General Corporation for Authorship, Translation, Printing, Publishing, and Associates Press, Cairo. Vol. 2-3. Hassan Qassem Habash Al-Bayyati, The journey of the Noble Qur'an from Jareed to Binding, Dar Al-Qalam, Beirut, $1^{\text {st }}$ ed, 1993, p. 4142. Muhammad Al-Maghraoui, (Moroccan fonts in manuscripts and documents), within the journal of "College of Arts \& Humanities, University of Muhammad V, Morocco, 2011, issue. 31, p.57. 
ornament the graphemic units of their writing systems, which has recently amounted to 40 systems. Moreover, some nations consider the use of Arabic letters in their modern languages. ${ }^{(50)}$

Therefore, it is evident that Arabic calligraphy, as an art, has always sought technical and aesthetic perfection; art "is no more than an aspiration for sublimity." (51)

As an artistic, aesthetic, cultural and civilizational phenomenon, Arabic calligraphy helped to capture the spirit of past times, as it embodied the nature of the times during which it developed. It has also contributed to enhancing calligraphers and artists' aesthetic taste that impacts on the collective subconscious of the community.

It is worth noting that the Holy Quran has endowed Arabic script with ontological conceptions and supported its basic structure. That is why one may feel that Arabic calligraphy is the incarnation of the magnificence of truth; it enhances the aura of the sanctity of Quranic miracles and rulings expressed in the Quranic script.

\section{The Aesthetic Features of Arabic Calligraphy}

The attraction of the Arabic script is attributed to its cursive letters, its being written from right to left and its ornate forms, in which the letters interpenetrate each other, brings joy, delight and amazement to onlookers, who may not find a logical justification for these feelings. This visual attraction is the other side of the rhythmical sounds of Arabic phonological structure; within the Arabic script, graphemes function as phonemes, or tunes, although the magic of these tunes cannot be logically defined; it can be felt, yet it cannot be explained. In some cases, graphical structures created by skilled calligraphers may amount to forms of artistic "miracles" that can be sensed by some onlookers, yet they cannot be explained.

This could be attributed to the aesthetic evocation made a distinctive feature of this art by distinguished calligraphers, including Qutbah Al-Muharrir (52), Ibn Muqla Abu Ali Muhammad (d. 328 AH) and his brother, Abu Abd Allah AlHasan (d. 338AH), Ibn Al-Bawab (d. 423 AH?) and Yaqut AlMusta'simi (d. 689 AH). This aesthetic value enables calligraphers to depict and communicate the social and cultural spirit of their time to be felt by onlookers of all times.

\section{The Aesthetic Dimension of Arabic Calligraphy: Artistic Practice, and Linguistic Functions}

Arabic calligraphy is a great example of aesthetic sophistication and has been widely analyzed and critiqued.

50 Abdullah Muhammad Ahmad Abu Nazifah, (The experience of writing the Mpa language in the standard Quranic letter), journal of "African Studies", 2010, Issue.43.

51 Denis Huisman, 1975, p.186.

$52 \mathrm{He}$ lived at the beginning of the Umayyad century
Its graphic units and structures have been explored, and it has never lost the potential to develop, although those who call for modernization believe that the opposite is the case. This is because the graphic systems of this calligraphy are free from limitations, and it is still governed by its original basics and retains its artistic value and function. "Original" here is intended to mean "not a copy of something else", to quote the Father of Arabic Linguistics, Abderahmane Haj salih ${ }^{(53)}$

A detailed examination of all types of calligraphy - and Arabic calligraphy in particular - as written discourse, which is contrasted with spoken discourse, would show that it comprises a variety of levels that are associated with linguistic functions, As in the following table:

Table 1. "The relationship of the Handwriting with the various levels, values, and linguistic functions",(54).

\begin{tabular}{llll}
\hline Level & $\begin{array}{l}\text { The nature of } \\
\text { the handwriting }\end{array}$ & $\begin{array}{l}\text { The value of } \\
\text { handwriting }\end{array}$ & Function \\
\hline Graphical & Read & Graphic & Inductive \\
Semantic & Understandable & Semantic & Clarity of meaning \\
Linguistic & Acceptable & Linguistic & Having a connection \\
Aesthetic & Loved & Aesthetic & Create fun \\
\hline
\end{tabular}

All levels of calligraphy are made to serve the aesthetic level, calligraphers' primary objective. This level brings joy and delight to onlookers. However, the least important level is the graphic one, as it is limited to deciphering written symbols.

It should be noted that failure to fulfill the requirements of the four levels, listed in the table, results in "bad handwriting", 55 ) as the four values (graphic, semiotic, linguistic and aesthetic) nonexistent.

Surprisingly, the literature on Arab heritage includes a reference to this type of handwriting, which offers no artistic value and performs no communicative function. For example, Al-Sawli (d.335 AH) and Al-Tha'alibi (d.429AH) said: "Bad handwriting is like a disobedient child or a disagreeable brother". (56)

\section{Conclusion}

The study draws the following conclusions:

1. Calligraphy is a human activity and the product of historical, social, and cultural conditions. Islamic civilization has endowed Arabic calligraphy with ontological potentials and epistemological values. This art comprises various graphic systems and linguistic relations and is the product of artistic creations by Arab and non-Arabs calligraphers. Owing to its originality

53 Abd Al-Rahman Hajj Salah, (Modern Khalilian Theory), within the Journal of “Language \& Literature”, University of Algiers, 1998, Issue. 10, p. 86.

54 Labidi Bouabdallah, 2007, p.208.

55 Labidi Bouabdallah, The bad handwriting, its manifestations, and its psychological and cognitive causes, a field study from a linguistic perspective, Dar Al-Amal for Printing, Publishing \& Distribution, Tizi Ouzou, Algeria, 2013, P.95.

56 Abu Bakr bin Yahya Al-Suli, The literature of writers, printed in Egypt, 1933. 1/16. Abu Mansur Al- Tha'alibi, Al- Tamthil wa Al-Muhazara, invest: Abd AlFattah Al-Hilu, Issa Al-Halabi Press, Cairo, 1961, 1/35. 
and potential to develop, this art had a very wide appeal and swept across the Muslim state. Therefore, it is the focus of aesthetic practice and elevates onlookers to sublimity and perfection.

2. The aesthetic value of Arabic calligraphy will never decline or abate because it has deep cultural roots. It derives prominence from its original and deeply rooted aesthetic value and embodies harmony between intellect and life. This is because beauty is the essence of life and the main source of delight and pleasure that we all seek by nature. The script is an essential part of human life, as it offers a visual representation of the concepts that we need to communicate with each other, and welcomes us to find out its aesthetic secrets.

3. The study tackled linguistic concepts and aesthetic dimensions that stem from aesthetics and reception theory, which is applied to creative discourse in various literary genres. This offers the possibility of linking all the aspects of this field together, specifically the field of linguistics, which has intellectual nature, purely scientific objectives, various artistic and cognitive subfields, and phonological and graphemic systems, that can be applied to a variety of artistic and cognitive fields. For example, it can be applied to the study of literature, literary criticism, psychology, sociology, the study of human communication and translation. This involves the adoption of an epistemological approach to the study of linguistic phenomena and the examination of civilizational, historical and cultural elements, and this is termed cultural linguistics.

\section{References}

[1] Abd Al-Ghani Al- Nabulsi, Nafahat Al-Azhar. World of Books, Beirut, and Al-Mutanabi Library, Cairo.

[2] Abd Al-Qahir Al-Jurjani, Dala'il Al- I'jez, invest: Mahmoud Muhammad Shakir, Al-Khanji Library \& Al-Madani Press, Cairo.

[3] Abd Al-Rahman Hajj Salah, (Modern Khalilian Theory), within the Journal of "Language \& Literature", University of Algiers, 1998, Issue. 10, p. 86.

[4] Abd Al-Salam Al-Masaddy, (Formulation of the term and its theoretical foundations), within the book: "The Foundation of the terminological Issue", prepared by: a group of university researchers, the National Institute for Translation, Investigation and Studies, House of Wisdom, Cartage, Tunis, 1989.

[5] Abdullah Muhammad Ahmad Abu Nazifah, (The experience of writing the Mpa language in the standard Quranic letter), journal of "African Studies", 2010, Issue. 43.

[6] Abu Bakr bin Yahya Al-Suli, The literature of writers, printed in Egypt, 1933.

[7] Abu Mansur Al- Tha'alibi, Al- Tamthil wa Al- Muhazara, invest: Abd Al-Fattah Al-Hilu, 'Issa Al-Halabi Press, Cairo, 1961.
[8] Adel Hadi Hammadi Al-Ubaidi, (The Issue of Pronunciation and Meaning), within journal of "Al-Ustaz", 2013, Issue. 201.

[9] Ahmad Al-Mufti, Arabic calligraphy rules, Dar bin Kathir \& Dar Al-Qadiri, Damascus \& Beirut, 1997, $1^{\text {st }}$ ed.

[10] Al-Haythami, Ali bin Abi Bakr, Majma'Al-Zawa'id, AlRayyan Heritage House, Cairo \& Dar Al-Kitab Al-Arabi, Beirut, 1987.

[11] Al-Makki Al- Nasiri, The Constitution of Tolerance in Islam, (without informations).

[12] Al-Mubarkafuri, Abu Al- A'la, Tuhfat Al- Ahwadhi, Dar AlKutub Al-'ilmiyya, Beirut, 1990, $1^{\text {st }}$ ed.

[13] Al-Qalqashandi, Abu Al-Abbas, Subh Al-A'sha, the Egyptian General Corporation for Authorship, Translation, Printing, Publishing, and Associates Press, Cairo.

[14] Al-Safa Brothers \& Khilan Al-Wafa, Al-Safa Brothers 'letters, Dar Sader, Beirut.

[15] Al-TTabarani, Sulayman bin Ahmad, The Middle dictionary, Invest: Tariq bin Awad bin Muhammad, \& Abdul Mohsen bin Ibrahim Al-Husayni, Dar Al-Haramayn, Cairo, 1995.

[16] Ammar Djidel, Dialogue of Civilizations and the Qualifications of Islam in Establishing Humanitarian Communication, Dar Al-Hamid for Publishing and Distribution, Amman, Jordan, 2003.

[17] Denis Huisman, Aesthetics, Translation: Zafer Al-Hassan, The National Company for Publishing \& Distribution (snad), Reghaia, Algeria, 1975, $2^{\text {nd }}$ ed.

[18] Ferdinand De Saussure, Cours de linguistique générale, édition critique, Preparation: Fullio de Mauro, ed Payot, 1980.

[19] Hassan Qassem Habash Al-Bayyati, The journey of the Noble Qur'an from Jareed to Binding, Dar Al-Qalam, Beirut, $1^{\text {st }}$ ed, 1993.

[20] Ibn Arabi Muhammad bin Ali, The Meccan Conquests, invest: Osman Yahya, review: Ibrahim Madkour, the Egyptian General Book Authority, Cairo.

[21] Ibn Hazm Al-Zahiri, Ali bin Ahmed, Al-Ihkam Fi Usul AlAhkam, Imam Press in Egypt.

[22] Ibn Kathir, Isma'il bin Omar, Tafsir bin Kathir, Dar Al-Fikr, Beirut, 1981.

[23] Ibn Khaldun, Abd Al-Rahman, Al- Muqaddimah, School Library \& Lebanese Book House for Printing \& Publishing, Beirut, 1979.

[24] John Lake Shalimu, The Graphical Icon, translation: Amara Kahali, within journal of "Semiotics", published by the Laboratory of Semiotics and Speech Analysis, University of Oran, Algeria, 2005, Issue. 01, p. 128.

[25] Labidi Bouabdallah, The bad handwriting, its manifestations, and its psychological and cognitive causes, a field study from a linguistic perspective, Dar Al-Amal for Printing, Publishing and Distribution, Tizi Ouzou, Algeria, 2013.

[26] Labidi Bouabdallah, (The concept of calligraphy and its functions, a linguistic, semiotic approach), within the Journal of "Arts \& Languages", 2007, Issue. 02, p. 199. 
[27] Muhammad Al-Maghraoui, (Moroccan fonts in manuscripts and documents), within the journal of "College of Arts \& Humanities, University of Muhammad V, Morocco, 2011, issue. 31, p. 57.

[28] Muhammad Al-Magri, The Form and The Discourse, An Introduction to Phenomenal Analysis, The Arab Cultural Center, Beirut, 1991, $1^{\text {st }}$ ed.

[29] Muslim bin Al-Hajjaj Al-Nisaburi, Sahih Muslim, 1912.
[30] Pierre Laurie, The Science of Letters in Islam, see: Dalia AlTToukhy, The Egyptian General Book Authority, Cairo, 2006, $1^{\text {st }}$ ed.

[31] Qasim Siza \& Abu Zayd Nasr Hamid, Introduction to Simiotics: Translated Articles \& Studies, (without information).

[32] Salim Al- 'alawi, (Sultan of the Spoken and Written), within the journal of "Language \& Literature". University of Algiers. 1996. Issue. 09, p. 25. 